\title{
Hypertrophic cardiomyopathy: the genetic determinants of clinical disease expression
}

\author{
Andre Keren, Petros Syrris and William J McKenna \\ Nature Clinical Practice Cardiovascular Medicine (2008) 5: 158-168 [doi:10.1038/ncpcardio1110]
}

\section{CORRIGENDUM}

In the March 2008 issue, Keren et al. stated that "Investigators in the Netherlands and South Africa have identified several MYBPC3 [the myosinbinding protein $\mathrm{C}$ gene] mutations that exhibit founder effects that account for at least $30 \%$ of cases of HCM [hypertrophic cardiomyopathy] in their respective populations [Moolman-Smook JC et al. (1999) Am J Hum Genet 65: 1308-1320; Tan HL et al. (2005) Circulation 112: 207-213]".
Although Moolman-Smook et al. have both reported numerous mutations in MYBPC3 and founder effects in the South African HCM population, to date they have not found, nor reported, any HCM founder mutations in MYBPC3. Rather, they have identified founder mutations in the $\beta$-myosin heavy chain gene (MYH7), which account for approximately $25-30 \%$ of South African $\mathrm{HCM}$ cases.
Published online 2 September 2008 www.nature.com/clinicalpractice doi:10.1038/ncpcardio1349

\section{Don't miss the following articles that will soon be appearing in the pages of Nature Clinical Practice Cardiovascular Medicine:}

\section{VIEWPOINT}

The relevance of prosthesis-patient mismatch after aortic valve replacement

Philippe Pibarot and Jean G Dumesnil

\section{CLINICAL ADVANCE}

Assessment of microvascular injury after acute myocardial infarction: importance of the area at risk Igor Klem and Raymond J Kim

\section{REVIEW}

Platelet ADP-receptor antagonists for cardiovascular disease: past, present and future

Nina C Raju, John W Eikelboom and Jack Hirsh

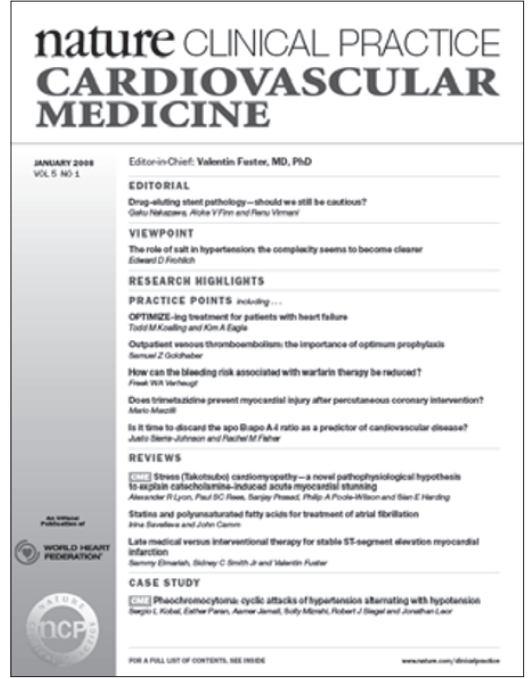

\section{CASE STUDY}

Acute hemodynamic changes in percutaneous transluminal septal coil embolization for hypertrophic obstructive cardiomyopathy

Steve Ramcharitar, Emanuele Meliga, Sharon W Kirschbaum, Folkert J ten Cate, Robert Jan van Geuns and Patrick W Serruys

Please note that the title details are not finalized and might be subject to change. 